\title{
A moderna cidade de São Paulo e as doenças do progresso, 1930 - 1970
}

\author{
André Mota \\ Professor Departamento de Medicina Preventiva FMUSP \\ a.mota@fm.usp.br
}

\begin{abstract}
Como citar este artigo: Mota, A. "A moderna cidade de São Paulo e as doenças do progresso, 1930 - 1970". Khronos, Revista de História da Ciência, no6, pp. 1-30. 2018. Disponível em <http://revistas.usp.br/khronos>. Acesso em $\mathrm{dd} / \mathrm{mm} /$ aaaa
\end{abstract}

Resumo: O estudo aqui apresentado traz como eixo central de análise, a relação estabelecida entre a cidade de São Paulo a partir dos anos de 1930, quando se vê em franco processo de metropolização com contornos de uma determinada modernidade, comportando não apenas reconfigurações urbanas e populacionais, mas também de enfrentamento de doenças novas e velhas que tomaram a cena e ajudaram explicar a cidade, a partir das chamadas "doenças do progresso". Com elas na pauta das autoridades médicas e de saúde, mas principalmente na vida de seus cidadãos, vai sendo possível compreender o desenho da cidade e o lugar dos indivíduos, noção central das arestas que comporiam a chamada "modernidade paulistana".

Palavras-chave: Cidade de São Paulo, Modernidade, Doenças do Progresso, Práticas Médicas e de Saúde Pública.

The modern city of São Paulo and the progress diseases, 1930 - 1970

\begin{abstract}
This article aims to present and comment on a pedagogical intervention developed in the science classroom, in the initial stage of the Fundamental II segment of Basic Education in the Youth and Adult Education modality, of a public school in the city of São Paulo, Brazil. The pedagogical intervention was part of an empirical research carried out from the planning, elaboration, validation, implementation and evaluation of a teaching learning sequence (TLS), based on a historical research developed for this purpose, that is, without having previously been published in textbooks. The pedagogical intervention is presented in this article based on its theoretical basis, followed by the research methodology, presentation of the printed material based on primary source that was used in the classroom, the analysis of the data collected and the conclusion of this intervention. Both this intervention and the empirical research itself revealed that the History of Science can be a teaching tool that favors the understanding of concepts of science and aspects of science and scientific research.
\end{abstract}

Keywords: City of São Paulo, Modernity, Progressive Diseases, Medical Practices and Public Health. 


\section{Introdução}

Quando estudamos a história das práticas médicas e de saúde em São Paulo no século $\mathrm{XX}^{1}$, há ainda um fato de que ressente parte de sua produção: trata-se de uma certa confusão encontrada em muitas narrativas que abordam sua historicidade, ou seja, fala-se do Estado de São Paulo como se não houvesse particularidades locais, de que emergiram questões que se devem compreender dentro de conjunturas específicas. Nesse sentido, discutimos aqui a sua capital, deixando claro que o impacto das legislações e ações médico-sanitárias foi sempre diferente e teve resultados também diferentes nos municípios e nas regiões de fronteira. Afinal, mais que uma ideia de região una e capaz de amalgamar a nação², o estado de São Paulo é, sobretudo, um espaço fragmentado geográfica e politicamente, com áreas por onde passam ou não os interesses do capital, o que fez toda a diferença para suas instituições médicas e de saúde pública. Foi a capital que categoricamente organizou os conceitos de tempo, cidade e urbanidade sobre São Paulo, permitindo entender o caminho que trilhou Milton Santos (1994, p. 71) para falar na "cidade e [n]o urbano como espaço-tempo", dimensões metodológicas que inspiram o olhar que se lança aos temas discutidos aqui:

[...] a cidade é ao mesmo tempo, uma região e um lugar, porque ela é totalidade, e suas partes dispõem de um movimento combinado, segundo uma lei própria, que é a lei do organismo urbano, com a qual se confunde. $\mathrm{Na}$ verdade, há leis que se sucedem, denotando o tempo que passa e mudando as denominações desse verdadeiro espaço-tempo que é a cidade. É através desses dois dados que vamos unir a cidade e o urbano. É desse modo que poderemos tentar ultrapassar o mistério das formas e buscar a construção do método, através da fenomenologia a adotar, a aproximação da contextualização, a reconstrução dos cenários de uma realidade que em parte se esvaiu, a busca do significado e da memória, uma memória que, através desse enfoque histórico, vamos encontrar expungida ao máximo dos filtros. Assim, nos é permitido dirigir perguntas à cidade, indagando a respeito de sua formação, já que a história da cidade é a história de sua produção continuada. A história de uma cidade se produz através do urbano que ela incorpora ou deixa de incorporar; desse urbano que em outros lugares pode tardar a chegar, e que em São Paulo sempre chegou quase imediatamente. Fala-se, por isso, na vocação irresistível de São Paulo pela modernidade. Mas que modernidade?

Uma possível definição de modernidade é de Koselleck³:

[...] quão nova é nossa modernidade? Para responder a essa pergunta, prosseguirei em dois passos. Primeiro, devo lembrar que a modernidade é, de

\footnotetext{
${ }^{1}$ MOTA, A. Tempos cruzados: raízes históricas da Saúde Coletiva no Estado de São Paulo 1920-1980. São Paulo, 2018 (Tese de Livre-Docência em Saúde Coletiva) - Departamento de Medicina Preventiva da Faculdade de Medicina, Universidade de São Paulo.

${ }^{2}$ LUCA, TR. São Paulo e a construção da identidade nacional. In: Ferreira AC, Luca TR, Iokoi Z. Encontros com a história: percursos históricos e historiográficos de São Paulo. São Paulo: Ed. Unesp/Fapesp/Anpuh; 1999b. p. 81-90.

${ }^{3}$ KOSELLECK, R. Estratos do tempo: estudos sobre a história. Rio de Janeiro: Contraponto/PUC-Rio, 2014.
} 
fato, nova. Essa resposta será fácil, pois quem duvidaria disso? Num segundo passo, perguntarei quão nova nossa modernidade de fato é? Essa resposta não será fácil. Ela nos confrontará com dificuldades que nós, historiadores, nos impusemos com a própria formulação do conceito.

Ao criticar as concepções que poderiam definir uma história como "mais nova" ou "mais velha", impondo categorizações do que é novo ou velho, o autor chama atenção para os estratos que compõem determinado tempo, ora acelerados, ora lentos e mais duradouros, ensejando sua repetição: "então, poderemos também redefinir as épocas temporais que fazem jus à modernidade, mas sem excluir as outras épocas de nossa história"".

A necessidade desse preâmbulo vai ao encontro justamente da São Paulo que se quer apreender: uma cidade que busca a modernidade, mas calçada por esses estratos temporais, dando azo a uma reflexão capaz de entender nesse processo como se configuraram certas pessoas nesses tempos e como as doenças nelas produzidas também fazem parte desses estratos temporais, ora lentos ou acelerados, ora bruscos ou a caminho, formadores de uma concepção de urbano e de vida na sociedade paulistana.

\section{Cidade de São Paulo: que modernidade?}

A Segunda Grande Guerra encerraria a chamada Era das Catástrofes apontando para uma nova fase do desenvolvimento humano, quando a economia mundial e o progresso social deveriam ser aliados no sentido de reconstruir o tecido social nacional pela incorporação de tecnologias e por um Estado de bem-estar capazes de incluir aqueles que estivessem fora de suas órbitas. No plano social, os grupos dominantes de outros tempos eram substituídos por uma mobilidade intensa, encontrada na expansão dos estratos médios e de um numeroso operariado ${ }^{5}$.

No caso brasileiro, ao processo desse crescimento econômico atrelava-se a crença na viabilidade de um país civilizado marcado pela concepção de progresso aliada à de sociedade moderna, respaldada no crescimento econômico do país, especificamente no surto industrial que imprimiria transformações de vulto na sociedade brasileira, particularmente na cidade de São Paulo. O projeto desenvolvimentista impulsionava o ritmo das atividades, carreando alterações de monta, referendando o ideário do progresso e acalentando a ilusão de que o Brasil construiria os pilares de uma moderna sociedade, tributária do desenvolvimento ${ }^{6}$.

Em sua clássica análise do processo de industrialização brasileiro, nos anos 1940-50, cheio de oscilações e submetido às intempéries internacionais, Caio Prado Jr. ratifica sua tese

\footnotetext{
${ }^{4}$ Ibid., p. 221.

${ }^{5}$ HOBSBAWM, Eric. A era dos extremos: o breve século XX, 1914-1991. São Paulo: Companhia das Letras, 1995.

${ }^{6}$ ARRUDA, MAN. Metrópole e cultura: o novo modernismo paulista em meados do século. Tempo Social (São Paulo). 1997; 9(2): 39-52.
} 
sobre a dependência brasileira internacional e seu caráter econômico, quase sempre provisório e ainda mantido por produtos primários, como o caso do café. Segundo o autor, a tendência do período foi de agravamento:

[...] através de crises e distúrbios financeiros graves que afetam profundamente as condições de vida da massa da população brasileira. É uma rápida desvalorização da moeda e consequente alta desmesurada e desordenada dos preços e custo de vida que, em geral, acompanham os surtos da indústria brasileira [...] o progresso se faz assim paradoxalmente em meio a grandes perturbações que afetam consideráveis setores da população ${ }^{7}$.

Evidentemente, o cotidiano da cidade de São Paulo já acusava havia algum tempo que esse quadro revelava as políticas que cercavam a questão, como também suas incongruências sociais, quase sempre sofridas pela população empobrecida e sem trabalho. A imprensa paulista do período repisava que, finalmente, a tranquilidade havia chegado a uma sociedade rica e próspera, embora fosse cotidianamente confrontada por uma imagem bastante diversa daquela apregoada:

[...] a posição dos liberais e antiliberais frente aos sem trabalho em nada se diferenciava. As propostas de internação dos menores abandonados em escolas, dos mendigos em asilos ou cadeias visavam isolar da sociedade a parte considerada doente. A presença dos "marginais" nas ruas oferecia a todos um espetáculo de pobreza que representava a negação da imagem social projetada pelos dominantes: de equilíbrio e paz ${ }^{8}$.

Esse momento carrega marcas particulares da construção mítica da São Paulo sem conflitos, apesar da relação entre o Estado e certos grupos populares considerados perigosos. A rua ganhou uma destinação normatizada, a de passagem e circulação, reservando àqueles que nela permaneciam a ação controladora e higienizadora dos representantes do Estado, organizando a cidade e "colocando cada coisa em seu lugar e em cada lugar uma coisa, evitando aglomerados por um lado e os perigos do vazio, por outro"9. Um exemplo esclarecedor é de 1934, quando passou a funcionar na capital a Delegacia Especializada de Repressão à Vadiagem, que visava conter os grupos pauperizados em determinados lugares:

[...] ainda dentro da preocupação com a vigilância e o controle da população pobre e desocupada que circulava pela cidade de São Paulo, foi criada em 1934 a Guarda Noturna da Capital. A Guarda passou a vigiar as ruas e os lugares frequentados pelas pessoas tidas por suspeitas, prendendo e encaminhando os considerados vadios à Delegacia de Repressão à Vadiagem, e os mendigos à Delegacia de Vigilância e Capturas ${ }^{10}$.

7 PRADO JUNIOR, C. História econômica do Brasil. 18a ed. São Paulo: Brasiliense; 1976, p. 331.

8 CAPELATO, MH. Os arautos do liberalismo: imprensa paulista - 1920-1945. São Paulo: Brasiliense; 1989, p. 133.

9 PECHMAN, RM. Os excluídos da rua: ordem urbana e cultura popular. In: Bresciani MS, organizadora. Imagens da cidade: séculos XIX-XX. São Paulo: Marco Zero/Anpuh/Fapesp, 1993, p. 33.

10 ZANIRATO, SH. São Paulo, 1930/1940: novos atores urbanos e a normatização social. História Social (Campinas, SP), 2000; p. 254. 
Nesse processo, a região central esteve na mira das autoridades no sentido de afastar, quando não controlar sob rígida estrutura policial, determinados grupos, quer por serem pobres, quer por carregarem outras marcas estigmatizantes como sua cor de pele, por exemplo. Foi assim que:

[...] em 1944, a polícia iniciou a "limpeza" da região central da cidade; fechando salões de dança e sistematicamente desfazendo aglomerações de negros. Depois de seguidas batidas policiais e de muitos protestos das organizações negras, conseguiu-se um acordo com a polícia, e a rua Direita continuou sendo uma espécie de território livre da sociabilidade negra, mas continuou sob permanente vigilância policial.

Dentro da lógica que se estabelecia e aprofundava, o ambiente era antes de tensão do que de paz, e esse sentido logo passou a figurar entre grupos mais sensíveis à questão. Um dos que se ressentiu das contradições do discurso do equilíbrio paulistano foi a elite letrada e envolvida, em tempos anteriores, com o projeto modernista de tornar São Paulo um símbolo urbano, com capacidade de romper com os valores do permanente passado colonial rumo a uma nova civilidade. Esse empreendimento logo se mostrou utópico, assistindo-se a cidade em seu acelerado processo de reafirmação das antigas e novas desigualdades sociais dissolvidas entre arranhacéus, avenidas e periferias abandonadas:

É essa cidade árida, rude, esmagadora, em que palpitam os milhões de esperanças solitárias, construída num curto espaço de tempo, no qual latejam múltiplas expressões de uma sensibilidade tolhida e tão evidente, nas festas animadas dos bairros populares e do futebol das várzeas periféricas, que Mário de Andrade canta no seu "Meditação sobre o Tietê", de 1945. Incorporando a imagem sinuosa do rio, que serpenteia silencioso pelos bairros pobres, à luz distante dos edifícios e do plano retilíneo das vias expressas, ele chora o destino frustrado de um sonho de emancipação que não se cumpriu${ }^{11}$.

Esse choro pela promessa não cumprida realmente trazia nas palavras de Mário de Andrade um símbolo paulistano muito representativo dessa cidade, que via agora em seu rio, outrora símbolo da pacatez citadina, as águas sujas e proibidas como a reafirmação de suas contradições:

$[\cdots]$

Na noite. E tudo é noite. Rio, o que posso fazer!... Rio, meu rio... mas porém há-de haver com certeza

Outra vida melhor do outro lado de lá

Da serra! E hei-de guardar silêncio

Deste amor mais perfeito do que os homens?...

Estou pequeno, inútil, bicho da terra, derrotado.

No entanto eu sou maior... Eu sinto uma grandeza infatigável!

Eu sou maior que os vermes e todos os animais.

E todos os vegetais. E os vulcões vivos e os oceanos,

Maior... Maior que a multidão do rio acorrentado,

Maior que a estrela, maior que os adjetivos,

${ }^{11}$ SEVCENKO, N. Pindorama revisitada: cultura e sociedade em tempos de virada. São Paulo: Peirópolis; 2000, p.103. 
Sou homem! Vencedor das mortes, bem-nascido além dos dias, Transfigurado além das profecias!

Eu recuso a paciência, o boi morreu, eu recuso a esperança.

Eu me acho tão cansado em meu furor.

As águas apenas murmuram hostis, água vil, mas turrona paulista

Que sobe e se espraia, levando as auroras represadas

Para o peito dos sofrimentos dos homens.

... e tudo é noite. Sob o arco admirável

Da Ponte das Bandeiras, morta dissoluta, fraca,

Uma lágrima apenas, uma lágrima,

Eu sigo alga escusa nas águas do meu Tietê $\hat{e}^{12}$.

Se as imagens contrárias provocaram as lágrimas de uma memória urbana que escorria rapidamente por entre as mãos de uma classe elitizada, é desse choque contrastante que se podem perceber as novas representações da e pela cidade, de um jogo de sentidos envolvendo progresso e tradição, formando o urbano e o rural num inesperado imaginário urbano:

[...] a dos populares deserdados do sistema, a dimensão da esfera pública, enquanto representação, e o imaginário constituído sobre o privado, as imagens do espaço que contrapõem o centro ao bairro ou ainda a própria visão da rua, vista como local de passeio ou passagem, contraposta àqueles que nela moram por não terem outra opção ${ }^{13}$.

Nesse sentido, procuramos aqui entender a cidade como artefato urbano, fadada a uma modernidade construída pelo tempo imediato, ou seja:

[...] a cidade é artefato, coisa complexa, fabricada, historicamente produzida. $\mathrm{O}$ artefato é um segmento da natureza socialmente apropriado, ao qual se impôs forma e/ou função e/ou sentido. Espaços, estruturas, objetos, equipamentos, arranjos gerais etc., todavia foram produzidos por força que não é possível excluir do entendimento: forças econômicas, territoriais, especulativas, políticas, sociais, culturais, em tensão constante num jogo de variáveis que é preciso acompanhar. Em última instância, o artefato é sempre produto e vetor desse campo de forças nas suas configurações dominantes e nas práticas que ele pressupõe $e^{14}$.

No caso paulistano, é do estilhaçamento dessas relações passadiças e de sua remontagem em novos contextos com suas representações e imagens do progresso sem limites que se configurarão a chegada de novas gentes, a tomada de terras e formas de viver de uma "outra" cidade, com muita marcação a partir da década de 1930, tomando dimensões metropolitanas. Com uma racionalidade cada vez mais complexa, vivendo mudanças que acabam por construíla e degradá-la, a capital paulista segue com sua estruturação administrativa fundada em limites

12 ANDRADE, M. Meditação sobre o Tietê. In: Lira paulistana, seguida de o Carro de Miséria. São Paulo: Martins Fontes, 1947, p. 55-56.

13 PESAVENTO, SJ. Muito além do espaço: por uma história cultural do urbano. Estudos históricos (Rio de Janeiro), 1995, 8(16), p. 286.

14 MENESES, UTB. Morfologia das cidades brasileiras: introdução ao estudo histórico da iconografia urbana. Revista da USP (São Paulo), 1996, p. 147. 
orçamentários, ineficácia administrativa e paralisia diante da intransigência das manobras especulativas:

[...] o crescimento físico da área urbana não foi acompanhado pelos poderes públicos, quer municipal, quer estadual, ocorrendo pela necessidade dos moradores da cidade e pela ação dos especuladores imobiliários, que ocuparam e lotearam regiões do entorno da cidade, em processo que continua até nossos dias ${ }^{15}$.

\section{A chegada dos “cabeças chatas": o processo migratório - 1930 - 1970}

Na virada do século XIX para o XX, a chegada de novos povos implicou uma explosão demográfica na capital e, aos poucos, logrou-se uma confusa acomodação entre imigrantes e nacionais, espraiados em cortiços, com esforços pontuais para criar moradias operárias e deslocamento para áreas menos valorizadas, caso das várzeas dos rios. Como bem definiu Sevcenko ${ }^{16}$, era uma cidade caracterizada por uma identidade difusa e estranha:

[...] afinal, São Paulo não era uma cidade nem de negros, nem de brancos, nem de mestiços; nem de estrangeiros e nem de brasileiros; nem americana, nem europeia, nem nativa; nem era industrial, apesar do volume crescente de fábricas, nem entreposto agrícola, apesar da importância crucial do café; não era tropical, nem subtropical; não era ainda moderna, mas não tinha mais passado. Essa cidade que brotou súbita e inexplicavelmente, como um colossal cogumelo depois da chuva, era um enigma para os seus próprios habitantes, perplexos, tentando entendê-la como podiam, enquanto lutavam para não ser devorados.

Os anos 1930 aprofundaram essa perspectiva, quando a população estabelecida assistiu a um novo e súbito aumento populacional, em função do processo migratório, agora essencialmente interno e notadamente de grupos vindos da Bahia, de Pernambuco, de Alagoas, do Sergipe e da porção setentrional de Minas Gerais. Para compreender esse deslocamento, é preciso sublinhar, particularmente, dois momentos do processo. O primeiro ainda é relativo à crise de 1929 e às necessidades da produção cafeeira no estado de São Paulo, quando:

[...] ao adquirir os estoques excedentes, construir uma infraestrutura de armazenamento do produto e elaborar uma política de desvalorização da moeda nacional, o Estado tornava-se sócio dos cafeicultores, socializando, assim, as perdas do setor por meio do encarecimento das importações e do endividamento externo. Entretanto, depois da grande crise, o governo teve que tomar medidas adicionais para manter a viabilidade econômica do setor. Essas políticas foram, basicamente, a queima de parte do estoque de café adquirido pelo Estado e o subsídio para contratar trabalhadores

15 GLEZER, R. Chão de terra e outros ensaios sobre São Paulo. São Paulo: Alameda, 2007, p. 173.

16 SEVCENKO, N. Orfeu extático na metrópole: São Paulo, sociedade e cultura nos frementes anos 20. São Paulo: Companhia das Letras, 1992, p. 31. 
(desta vez, migrantes nacionais) com o fito de sanar o problema da "falta de braços" nos cafezais paulistas ${ }^{17}$.

O governo estadual subsidiou o processo migratório, o que acabou, por um lado, concorrendo para a recuperação da cafeicultura e, por outro, promoveu uma acumulação de força de trabalho industrial das grandes cidades, sobretudo na capital. Paulatinamente, diminuiu a produção cafeeira e surgiu uma crescente diversificação de culturas no oeste paulista como o plantio de laranja, cana-de-açúcar, feijão, milho e algodão, o que permitiu o deslocamento de parte dessa população para as grandes cidades, iniciando a formação de uma reserva de trabalho para as indústrias e o setor de serviços:

[...] o então governador do estado de São Paulo, Armando de Salles de Oliveira, por meio da Secretaria da Agricultura, reeditou, em 1935, uma política de estímulo à migração de trabalhadores nacionais, baianos e mineiros em sua maioria, em direção às lavouras do interior. Os deslocamentos desses trabalhadores eram realizados com subvenção oficial por meio de contrato com empresas particulares de imigração e colonização, e ficava a cargo do Estado o pagamento das passagens e do transporte de bagagens dos migrantes [...]. Em 1939, ocorre uma mudança significativa na política migratória do estado que desarticulou os interesses das companhias privadas: a criação da Inspetoria de Trabalhadores Migrantes (ITM). Essa Inspetoria possuía uma estrutura própria de agentes contratantes, com escritórios nas cidades de maiores influxos de migrantes interessados em entrar no estado de São Paulo ${ }^{18}$.

Entre 1935 e 1939, dos 285.304 trabalhadores e trabalhadoras que entraram na Hospedaria dos Imigrantes, 96,3\% eram brasileiros ${ }^{19}$. Um segundo movimento, que de alguma forma deu sequência ao processo, posto que não cessou a vinda de migrantes, mas a intensificou a partir do pós-guerra, ocorreu com o projeto nacional-desenvolvimentista de Getúlio Vargas, aprofundando-se na planificação de Juscelino Kubitschek, nos anos 1950, com alto investimento no parque industrial brasileiro. Essa nova configuração da atividade produtiva industrial aumentou as oportunidades de emprego nos grandes centros urbanos e no setor industrial paulista, que abrangia a capital e cidades vizinhas, como o chamado ABC:

Diferentemente do período anterior, o Estado não mais subvencionaria o recrutamento e o deslocamento da força de trabalho que se dirigia à metrópole paulista e carioca. Tratava-se de uma "migração espontânea", em que os próprios migrantes arcariam com as despesas da empreitada [...] realidade marcada pela desapropriação, pela seca, pela desestruturação do campesinato; enfim, não se tratava apenas de uma alocação ótima dos fatores de produção do espaço, mas sim de um processo social cuja base

${ }_{17}$ SILVA, UV. Velhos caminhos, novos destinos: migrantes nordestinos na Região Metropolitana de São Paulo [Dissertação de Mestrado em Sociologia), 2008 - São Paulo: Departamento de Sociologia, Faculdade de Filosofia, Letras e Ciências Humanas, Universidade de São Paulo, p.19.

18 Ibidem.

${ }^{19}$ FONTES, P. Um nordeste em São Paulo: trabalhadores migrantes em São Miguel Paulista 1945-1966. Rio de Janeiro: FGV, 2008, p.45-46. 

volvimento econômico cujo eixo estruturador era a indústria moderna ${ }^{20}$.

Com o impacto desse contexto, a atração de trabalhadores recrudesceu, tomando a dimensão de um verdadeiro êxodo rural, estimulada, sobretudo, pelas secas da região nordestina de 1951-53 e a de 1958. Entre 1951 e 1955, o Departamento de Imigração e Colonização registrou a entrada de 762.707 migrantes na cidade, representando um crescimento de aproximadamente $60 \%$. Com isso, o tamanho do município triplicou, enquanto, no mesmo período, a população nordestina cresceu dez vezes, empregando-se em massa nos vários ramos da indústria e de serviços, em franca expansão na Região Metropolitana de São Paulo²1.

A imprensa local acusava essa chegada, mas com um deslocamento discursivo importante: não se tratava somente de trabalhadores e suas famílias, mas de uma "certa gente", até certo ponto considerada nociva e ameaçadora:

[...] quem olha para as cenas fixadas nos clichês acima, pensa que se trata de criaturas atingidas pelas crueldades da guerra em algum lugar da Europa devastada e faminta. Quadros comovedores, denunciando a miséria e o sofrimento de seres esquecidos de Deus. Assim não é, contudo. São dolorosos quadros apanhados no Brasil, mesmo aqui em São Paulo, na Estação Presidente Roosevelt. São patrícios nossos, nossos irmãos, que o destino dos órgãos que superintendem a migração nacional jogou, sem mais esta ou aquela, às regiões de Piratininga ${ }^{22}$.

Dias depois dessa notícia, o deputado Miguel Petrilli propunha na Assembleia Legislativa de São Paulo uma representação para exigir dos órgãos executivos providências no sentido de amparar esses grupos:

[...] famílias inteiras, crianças maltrapilhas e desnutridas que são vistas por aí na mais negra miséria, ao relento, sem que os poderes competentes tomem qualquer iniciativa, visando amparar os nossos "desgraçados" patrícios que se embalam de seus longínquos rincões, acossados pela fome e pelas moléstias, em busca de um terra em que eles acreditavam encontrar todas as facilidades de viver ${ }^{23}$.

O governo paulista parecia indiferente ao que ocorria, inclusive à infraestrutura necessária para recebê-los institucionalmente, como foi o caso da Hospedaria dos Imigrantes, oficialmente responsável por acolher e distribuir as famílias entre as regiões do estado onde houvesse necessidade de mão de obra. Em 1952, o jornal O Estado de S. Paulo voltou a falar das levas de nordestinos que entravam na capital sem nenhum controle. Chegariam doentes e subnutridos,

${ }^{20}$ FONTES, P. Um nordeste em São Paulo: trabalhadores migrantes em São Miguel Paulista 1945-1966.

Rio de Janeiro: FGV, 2008, p. 26.

${ }^{21}$ Ibidem.

22 A Gazeta, 4 mar. 1947, p. 1.

${ }^{23}$ O Estado de S. Paulo, 11 de setembro, 1947, p. 5. 
com conjuntivite, diarreia e tuberculose, resultado da longa viagem realizada e a Hospedaria, dizia-se, quase não prestava os serviços adequados:

[...] o serviço médico da Hospedaria de Imigrantes é o mais precário possível. Não dispõe de nada, absolutamente nada, a não ser da boa vontade e dedicação de seus profissionais, que se encontram na dura contingência de limitar o exercício de suas funções à verificação perfuntória do aspecto geral dos trabalhadores nordestinos que para lá caminham, na alarmante média diária de 1.500 pessoas ${ }^{24}$.

Indo além, o jornal colocava em pauta a necessidade de seleção, já que doentes e insanos estariam aprofundando a crise, além de não corresponder à força de trabalho esperada, quer para as lavouras do interior, quer para o trabalho na capital. Era preciso que essa gente chegasse, mas não toda ela, apenas os produtivos e sãos:

[...] presentemente, existe a presunção, baseada em verificações comprovadas em outros centros, da entrada de trabalhadores nordestinos portadores de moléstias infecciosas. Mas que se poderá fazer quando tais moléstias realmente se comprovarem? Poderá o Estado devolver às regiões de origem os indivíduos afetados e reter apenas os bons? ${ }^{25}$.

É desse movimento contraditório, que ora se refere a trabalhadores bem-vindos, ora a uma massa inútil ao projeto paulistano, que se foi configurando paulatinamente um complexo campo de forças de que emergia no estado de São Paulo o preconceito contra os nacionais em geral e os nordestinos em particular. É bom lembrar que essas insinuações não nasceram naquele momento, mas vinham sendo construídas em tempos anteriores, exemplarmente, como nos anos que fizeram eclodir a guerra civil de 1932, momento propício para:

[...] o acirramento das hostilidades contranaturais de outros estados, a despeito de a população de São Paulo ser composta de famílias oriundas de todas as partes do Brasil. Especialmente os nordestinos foram vítimas de um preconceito xenófobo, que nas semanas de conflito assumiu contornos perigosos de ódio explícito ${ }^{26}$.

Exemplarmente em 1931, quando Getúlio Vargas anunciou o pernambucano João Alberto $^{27}$ como interventor federal, a reação paulista assumiu várias formas. Imediatamente após a nomeação, o jornal O Separatista cunhou uma expressão que se instalaria no imaginário paulista: "cabeça chata", significando implicitamente ignorante e semibárbaro:

[...] o primeiro número traz uma pequena história, intitulada "Aventuras de um cabeça chata", sobre o cearense Aniceto de Menezes, "nascido hipoteticamente na cidade de Quixeramobim", que ao chegar em São Paulo

\footnotetext{
${ }^{24}$ O Estado de S. Paulo, 02 de outubro de 1952, p. 8.

25 Idem.

${ }^{26}$ SANTOS, MAC; MOTA, A. São Paulo, 1932: memória, mito e identidade. São Paulo: Alameda, 2010, p. 71.

${ }^{27}$ Interventor federal no governo de São Paulo de 26 de novembro de 1930 a 25 de julho de 1931.
} 
consegue um emprego muito bem remunerado com seu amigo, o interventor João Alberto. Ao receber seu primeiro salário, Aniceto achou que estava sendo enganado, pois recebera notas que julgava falsas por não existirem naquele valor. Segundo o jornal, "era a primeira vez que um cabeça chata via nota de um conto de réis". A provocação, o escárnio e a ofensa aos nordestinos foram retomados no terceiro número de O Separatista, nos textos: "Monumento a Lampeão", "Um cabeça chata" e "Seca no Nordeste" 28

Às consequências desse tipo de narrativa no convívio social paulistano se somaria a outra categorização, como vimos em capítulos anteriores, formulada particularmente pelas lentes de cunho eugenista do pensamento médico-sanitário, que via nesses nordestinos, quase todos mulatos, um símbolo de ameaça racial, pois estariam aprisionados em sua degeneração física e social. Os anos de 1940 repisariam essa mesma concepção para o público geral, visão disseminada de todas as formas, como em "Trapézio cerebral", crônica da imprensa paulistana que conta a história de dois protagonistas cujo nome não se divulga porque, segundo a autora, seriam "reais":

[...] são dois mulatos, dois seres marginais, como é moda dizer-se, agora que a literatura deu a tomar termos emprestados da sociologia. Marginais em todos os sentidos, já que, colocados fora da sociedade burguesa como meninos da favela, não se adaptaram, por outro lado, ao meio onde haviam nascido, muito acima do qual se elevava a superioridade intelectual forrada, evidentemente, de uma justa ambição [...] ao cabo de alguns anos, ambos poderiam se considerar vitoriosos, professor um, jornalista o outro. Até aqui, o caso é edificante e simples, mas agora surge o problema, põe a ponta do nariz para fora, pisca um olho. A família dos dois amigos - que o eram e inseparáveis - não haviam nem de longe acompanhado na ascensão. Os pais, irmãos continuavam broncos, analfabetos, presos à sua miserável condição. Entre eles e os seus, não havia nada de comum, a não ser o sangue cuja decantada voz nem sempre é audível. Deveriam fazer vida a parte ou permanecer na comunhão familiar? (Pereira LM, 1946, p. 4).

Nessa narrativa, o professor que se afastou de sua família tornou-se morigerado, casouse com uma mulher branca, e a vida seguiu a passos largos. Já o jornalista, que resolveu ficar com sua família mulata, viu sua vida decair:

[...] tornou-se impaciente, irritado, azedo. Ainda longe dos seus, não tinha a antiga bonomia. Os seus artigos eram agora ferinos, agressivos deixando pressentir a revolta que lhe mudava o temperamento. Morigerado a princípio, fez-se boêmio e começou a beber para esquecer seus tormentos. Era frequente chegar embriagado, rosnando impropérios, insultando aos irmãos, que a tudo culpava. Com a bebida, sofreu o trabalho, conheceu dificuldades de dinheiro, que procurou remediar com o jogo para pormenorizar lhe a degradação. Digamos logo que, num dia de lúcido desespero,

${ }^{28}$ SANTOS, MAC; MOTA, A. São Paulo, 1932: memória, mito e identidade. São Paulo: Alameda, 2010, p. 72. 
resolveu que a comédia já durara demais e era chegado o momento da tragédia, isto é, do suicídio (Pereira LM, 1946, p. 4).

Em tal conjuntura, termos estigmatizantes amalgamavam representações em torno dos nordestinos que passaram a habitar na cidade, todos cognominados, com o tempo, como "baianos" - afinal, “de Minas para cima, é tudo Bahia” -, generalização que redundou numa enxurrada de definições depreciativas, somando-se às "pestes" que teriam trazido em sua bagagem, corroborando em:

[...] várias possibilidades de leitura do nordestino como mendigo, visto como falso em grande parte das vezes; como indigente, como vítima flagelada ou criminoso, silenciando sobre sua participação na formação da classe trabalhadora de São Paulo, que garantiu o desenvolvimento do projeto de modernização do país na década de 50 . E foi dentro desse enquadramento, também de proliferadores de doenças, que se criaram novos significados para sua presença na cidade de São Paulo, muitas deles assimilados pelos "paulistas". Talvez seja bom exemplo a fala da moradora da Mooca, que, diante dessas notícias que chegavam, vociferou nos anos de 1980: "Eles empestaram tudo, deveriam voltar tudo pra lá"29.

\section{As doenças do progresso e a busca de assistência}

Em 1985, o historiador Jacques Le Goff organizou a obra As doenças têm história, chamando atenção para o fato de o corpo em sofrimento por doenças tornar-se objeto da história. Assim, não estaria o homem frente às doenças ligado apenas aos progressos científicos e tecnológicos da medicina e de seu campo de saberes e práticas, mas, antes de tudo, por expressar “a história mais profunda dos saberes, das práticas ligadas às estruturas sociais, às instituições, às representações, às mentalidades" ${ }^{30}$. Também se trata de um jogo da doença e da saúde que, ao sair da casa do doente e se deslocar para o hospital, passou a mediar a vida social coletiva, publicizando limites e obstáculos nessa empreitada. O autor aponta uma construção historicizada por homens e mulheres num certo tempo, de doenças que aparecem, desaparecem e reaparecem tensionadas pelas opções humanas de viver em determinada sociedade.

No caso das sociedades ocidentais e desde a modernidade, a medicina e os médicos procuraram intervir no corpo individual e social lidando com endemias e epidemias num processo que trazia, em seu discurso e em suas práticas, cada vez mais cientificizados, uma dose de otimismo, "otimismo que revela a mesma ilusão que nos faz esquecer de que somos mortais" 31 . Nasciam assim termos diferentes, sem poder ser isolados ou destituídos de arbitrariedades, como

\footnotetext{
${ }^{29}$ ROMERO, M. Nordestinos em São Paulo nos anos de 1950: imprensa popular, ciência e exclusão social. In: Anais Eletrônicos do XXI Encontro Estadual de História da Anpuh-SP. 2014, Santos, SP, p.10.

${ }^{30}$ LE GOFF, J. Uma história dramática. In: Le Goff J, organizador. As doenças têm história. Lisboa: Terramar; 1991. p. 8.

${ }^{31}$ MOULIN, AM. Os frutos da ciência. In: Le Goff J, organizador. As doenças têm história. Lisboa: Terramar; 1991. p. 95.
} 
disease para as entidades mórbidas conhecidas pela ciência médica de uma época, illness para as formas de representação social da doença, dos sintomas e da evolução, e, finalmente de uma visão que nos conduz à diversidade das culturas humanas, com sickness designando "a imagem da doença na sociedade: quais são as reconhecidas, tidas como curáveis, aquelas de que a sociedade aceita a responsabilidade (poluição, doenças profissionais etc.)"32. Nesse espectro de definições, o mundo da indústria passou a refletir, com vigor a partir dos anos 1920, uma medicina cada vez mais voltada ao controle e à distinção do comportamento individual e de suas potencialidades produtivas fabris, ganhando espaço no pensamento médico brasileiro e paulista fundamentalmente a partir de 1931, com a criação do Instituto de Organização Racional do Trabalho (Idort), desdobrando-se nos anos 1940-50 em entidades como Senai, Senac e o Sesi, preocupados em ter e produzir trabalhadores "sãos", apostando sobretudo em sua capacidade de produzir e submeter-se ao mundo do trabalho.

Um médico emblemático nessa função foi Arlindo Ramos, da Divisão de Higiene e Segurança do Trabalho do Serviço Público Federal, reconhecido por Roberto Simonsen como o mais importante psicotécnico do país:

[...] proclamando-se discípulo de Taylor, o dr. Ramos assumiu como tese dominante no seu principal estudo, o princípio de que, mesmo para "os cargos de responsabilidade", o importante não era tanto a aplicação de "testes de inteligência", mas sim exames que poderiam assinalar a existência de distúrbio pré-psicóticos, facilitando a operação de alijamento dos "doentes" do mundo da produção. Para realizar o "exame de temperamento e personalidade", o médico enfatizou a necessidade de recorrência a uma série de dispositivos que certamente causavam assombro à mão de obra avaliada. Inicialmente, o candidato era instado a se submeter ao psicodiagnóstico segundo os protocolos de Rorschach para, sem seguida, responder "sim" ou "não" a 116 perguntas componentes do inventário de Woodworth-Mathews que, adaptado para o contexto brasileiro, compreendia questões como as seguintes: Você é mais medroso que os outros? Você às vezes sonha com mortos? Você pode ficar sentados durante muito tempo sem se mexer? Você resiste à dor tanto quanto os outros? Você acredita em azar? Você já sentiu vontade de provocar um incêndio? Você gosta de caçar? e você já teve vontade de roubar.

Nessa perspectiva, Marc Ferro fala nos "sintomas sociais" das doenças produzidas pela ideologia do progresso, justamente pela combinação de um estado clínico considerado de desvio e anormalidade frente ao sistema socioeconômico imposto: "a doença tão depressa se manifesta como uma forma de resistência passiva à organização do trabalho, à injustiça e à desigualdade; tão depressa, pelo contrário, como um efeito da desorganização do trabalho, da insegurança, da pressão que a situação atual exerce" ${ }^{33}$. Nesse sentido, mesmo que possamos compreender que o desenvolvimento da ciência ensejou, em escala mundial, uma melhoria constante e geral da saúde

32 Ibidem, p. 97.

${ }^{33}$ FERRO, M. As sociedades doentes do progresso: Lisboa: Piaget, 1999, p. 17. 
desde há mais de um século, decorrendo, em determinados grupos da sociedade, o aumento da esperança de vida, é bom que se diga:

[...] ela não entra sozinha em linha de conta. E a observação contrária é simultaneamente válida, a saúde degrada-se. O estado de saúde constitui um indicador da reação dos indivíduos à mudança de vida a que estão submetidos e, desse ponto de vista, a doença torna-se um sintoma de malestar social $[\ldots]^{34}$.

Essa ideia merece atenção, pois esclarece as mudanças repentinas e explosivas que se deram na cidade de São Paulo, envolvendo deslocamento populacional e formas de moradia e trabalho, mesmo que os discursos procurassem dissolver as contradições por meio de uma série de dispositivos capazes de uma interpretação ligada a uma possível harmonia da realidade, bastando acionar a responsabilização individual frente às ameaças da vida e do trabalho produtivo: da boa nutrição ao bom sono, dos cuidados para se manter o equilíbrio sexual às dicas sobre vestimentas, todas contribuíam para as representações que se coadunavam com a Educação Sanitária, agora e mais que nunca aliada à nascente indústria de fármacos, que espalhava seus folhetos educativos e de automedicação por bondes, trens e outdoors:

[...] a harmonia para produção e os remédios para adequação ao trabalho retiram qualquer suspeita que possa recair sobre as relações sociais contraditórias. As enfermidades e os descompassos resultam de fatores atemporais, a sociedade em crise é um dado em si, impenetrável. Portanto, as doenças não podem ser o resultado dessa constituição social, mas antes, a etiologia encontra-se na falha de decisão de indivíduos isolados, já que o excesso de trabalho, o caos urbano, a insalubridade fabril etc. são fixados como partes indissociáveis do todo, rígido e inexorável. Dessa forma, o espaço de atuação possível fica relegado à conscientização sanitária do indivíduo, a atuação incompleta dos órgãos públicos de saúde e a decisão pelo consumo dos medicamentos comercializados abertamente ${ }^{35}$.

No entanto, se tinham alguma resposta positiva, os resultados dessa empreitada conviveriam sempre com uma contradição derivada da crise urbana, desaguando em problemas sanitários de toda ordem, além de endemias e epidemias que avançavam na mesma progressão e velocidade com que surgiam habitantes e indústrias, compondo um quadro desolador, conforme o editorial de $A$ gazeta de 10 abril de 1947 (p. 1):

As condições higiênicas da capital pioram dia a dia. O serviço de saúde pública anda ausente de muita coisa. Se não fosse a proteção dos céus, porque Deus não abandona nunca a gente piratiningana, a essas horas sentiríamos calamitosos efeitos da falta de melhor e maior zelo pelo estado sanitário da urbs. Em assunto de higiene, a desolação é completa. Não existe nas vias públicas, de onde a limpeza fugiu. Não se desinfetam, nem se fazem desinfetar obrigatoriamente as moradias, onde a escassez de habitações amontoa dezenas e dezenas de pessoas. Assim nos porões, assim nos cortiços. Também nas casas de pensão e hotéis [...] no mercado, na

\footnotetext{
${ }^{34}$ Ibidem, p. 77.

35 RODRIGUES, GK. Não há cura sem anúncio: ciência, medicina e propaganda, São Paulo 1930-1939 [dissertação]. São Paulo: Pontifícia Universidade Católica de São Paulo, 2015, p. 115.
} 
feira, é revoltante o abuso na venda de frutas, verduras e legumes deteriorados e podres. Ovos igualmente. Qual repressão se adota ou determina o serviço de higiene, castigando os infratores? É mistério... Ronda tifo nos bairros. Às vezes, a varíola aponta em surtos esporádicos. E a febre amarela ensaia através dos mosquitos veiculadores. Escarlatina, tuberculose, sífilis $[\ldots]$.

Desse modo, das doenças a suas expiações, a vida cotidiana paulistana parece apagar muitas dessas experiências, numa velocidade que quase explica que adoecer seria apenas um fenômeno biológico e de cunho individual, mesmo sob a indicação de suas causas sociais e dos levantamentos epidemiológicos. Mais que isso, deixava para trás as responsabilidades no campo da assistência médica e sanitária como se tudo o que se pudesse fazer estivesse já encaminhado pela máquina médico-sanitária paulista, dentro e fora de suas instituições. Um passeio por São Paulo e a simples aproximação de certas doenças - algumas bastante conhecidas e outras de causas inéditas - revela o cotidiano da população e os reflexos dos serviços de saúde e dos médicos, que, quando funcionavam, funcionavam para poucos. Muito poucos.

\section{Esquistossomose: o abandono das periferias e dos nordestinos “empesteados"}

A esquistossomose mansoni em São Paulo poderá explicar parte desse processo. Sua implantação inicial se deu em uma extensa faixa do litoral, principalmente nas regiões onde se processava a cultura canavieira e, posteriormente, para todo o território brasileiro. Apesar dessa dispersão, sua maior concentração, entretanto, se deu nas áreas iniciais da cultura canavieira, principalmente os estados da Bahia e Pernambuco, traduzidos ainda hoje como regiões de alta endemicidade, seguidos pelos estados limítrofes (Carvalho, 1982).

Foi no ano de 1908 que, no Laboratório de Análises Clínicas, instalado no Hospital Santa Isabel, da Bahia, o assistente de clínica médica, Pirajá da Silva, examinando fezes de pacientes internados em seu serviço, verificou tratar-se de ovos de vermes dotados de um espículo lateral cuja proveniência intrigou a comunidade científica: não eram mera variante encontrada no Egito do Schistosoma haematobium, mas constituíam uma nova espécie, batizada então pelo prof. Sambon com o nome Schistosoma mansoni (Falcão, 1959, p. 15). Pelo aumento dos infectados e pelos estudos produzidos, acusou-se, entre os anos de 1950 e 1970, uma expansão territorial das áreas endêmicas de esquistossomose no país, assinalando focos de transmissão em São Paulo, no Paraná, no Piauí, no Maranhão, em Goiás e em Santa Catarina.

Em Crescimento urbano e doença: a esquistossomose no município de São Paulo, aponta-se que os prováveis primeiros casos da esquistossomose teriam chegado ao estado de São Paulo ainda na primeira metade do século XIX, no auge da cafeicultura (Santos NR, 1967). Outro ponto interessante a ser notado é que: "a ocorrência autóctone de esquistossomose no estado de São Paulo 
é identificado no ano de 1923, quando os primeiros casos são descritos em Santos"36 (Silva LJ, 1985, p. 3). Na década de 1940, ainda havia focos de infestação em vários pontos do município:

[...] o foco de esquistossomose foi localizado no bairro do Saboó, estando atualmente 115 pessoas infectadas. A doença foi diagnosticada em 1940, pelo dr. Leão de Moura, o qual, agora, retomando os estudos, examinou mais de 1.000 caramujos Planorbis, encontrando meio por cento delas infestados, além de $10 \%$ em 1.200 pessoas examinadas, todas elas residentes na zona do Saboó ${ }^{37}$.

Passando a ser veiculada por estudos e pela imprensa jornalística nos anos 1940-50 e mesmo em trabalhos posteriores, a informação merece revisão, tendo em conta a facilidade com que os casos de esquistossomose passaram despercebidos até então, já que a presença da doença nem sempre era identificada. Além disso, a década de 1940 foi a "época do despertar do meio médico brasileiro com relação à esquistossomose. Basta dizer que, de 1908 a 1939, a literatura brasileira registrou 107 trabalhos sobre esquistossomose, no entanto, entre 1940 e 1949, foram publicados 202 trabalhos.

Avaliando a capital paulista e os primeiros casos identificados e largamente transmitidos por veículos acadêmicos (Meira, 1951) e de imprensa, a questão da migração apareceu quase sempre como único fator determinante, sobretudo em razão da chegada de nordestinos. A eles, e quase somente a eles, imputava-se a responsabilidade pela proliferação do parasita, sendo a cidade de São Paulo considerada uma área potencialmente endêmica, exatamente pelo fluxo migratório originário de áreas endêmicas de esquistossomose, que perdurou pelo menos até os anos $1970^{38}$.

Em levantamento publicado pelo Instituto Adolfo Lutz em 1953, a questão da imigração era o centro do problema da esquistossomose em São Paulo, assim como os motivos desse deslocamento. Dizia o estudo:

É do conhecimento geral a intensidade do movimento imigratório originário de estados pertencentes às zonas geográficas Nordeste e Leste do país e que tem como meta o estado de São Paulo e a região do norte do Paraná. Esse movimento migratório, cujos fatores determinantes são de ordem telúrica e econômico-social, tem recrudescido nos anos anteriores, transformando-se em verdadeiro êxodo nos anos de 1951 e 1952 [...], quando atingiu as cifras de 208.515 e 252.808 . Através da corrente imigratória, foi a esquistossomose introduzida em Minas Gerais, em nosso estado, como em Santos, São Vicente e Itapema, em Ourinhos, Palmital e Ipaussu e, no Paraná, em Jacarezinho e em Uraí. O perigo potencial que a

36 SILVA, LJ. Crescimento urbano e doença: a esquistossomose no município de São Paulo. Revista de Saúde Pública (São Paulo). 1985; 19(1), p. 3.

37 A Gazeta, 15 set. 1945, p. 10.

${ }^{38}$ CHIEFFI, PP; WALDMAN, EA. Aspectos particulares do comportamento epidemiológico da esquistossomose mansônica no estado de São Paulo, Brasil. Cadernos de Saúde Pública (Rio de Janeiro). 1988; 4(3): 257-75. 
referida imigração representa tem sido objeto de repetidas advertências de nossos pesquisadores, tornando-se mesmo enfadonho repisar o assunto ${ }^{39}$.

De acordo com os resultados, a incidência da esquistossomose entre os migrantes segundo o estado de origem era identificada com segurança.

Quadro 2 - Schistosoma mansoni na cidade de São Paulo

\begin{tabular}{lccc}
\hline Estado & $\begin{array}{c}\text { imigrantes exa- } \\
\text { minados }\end{array}$ & $\begin{array}{c}\text { positivos para ovos de } \\
\text { Schistosoma mansoni }\end{array}$ & percentual \\
\hline Alagoas & 253 & 124 & $49,0 \%$ \\
\hline Sergipe & 88 & 30 & $33,9 \%$ \\
\hline Pernambuco & 158 & 33 & $20,8 \%$ \\
\hline Bahia & 274 & 53 & $7,5 \%$ \\
\hline Paraíba & 40 & 3 & $5,0 \%$ \\
\hline Minas Gerais & 100 & 5 & $0 \%$ \\
\hline Ceará & 65 & 0 & $0 \%$ \\
\hline Rio Grande do Norte & 24 & 0 & $0 \%$ \\
\hline Piauí & 8 & & \\
\hline
\end{tabular}

FONTE: Corrêa $\mathrm{MOA}^{40}$.

$\mathrm{Na}$ década de 1950, os casos da transmissão eram identificados, principalmente em áreas próximas ao rio Tietê. Assim foram dois casos de esquistossomose Manzoni autóctone encontrados nas lagoas do Tatuapé, afluentes do Tietê, cabendo lembrar que, desde o começo do século XX, as autoridades já vinham discutindo o rio, sem nada decidir sobre o processo de poluição de suas águas ou sobre o saneamento básico e a cloração da água, argumentos centrais dos agentes de saúde. Essa pendência e a deterioração constante do Tietê não deixavam dúvidas:

[...] no início dos anos de 1940, o rio Tietê era um rio cada vez mais degradado e perigoso para a maioria dos seres vivos que se aproximavam de suas águas. Entretanto, nessa época, não havia quem acreditasse que o principal rio de São Paulo e seus afluentes seriam recuperados. Ainda mais

39 CORRÊA, MOA. Incidência da esquistossomose mansoni em imigrantes oriundos de outros estados. Revista do Instituto Adolfo Lutz (São Paulo). 1953; 13(1-2): p. 91.

40 Ibidem, p. 95. 
porque funcionários da própria Repartição de Águas e Esgotos manifestavam publicamente essa convicção ${ }^{41}$.

Foi nesse contexto que se suspendeu uma prova de natação no rio Tietê, até então uma tradição da cidade conhecida como "Travessia de São Paulo a nado". O motivo seriam os resultados de uma avaliação das águas do rio pelo Instituto Adolfo Lutz, que isolou e identificou um germe do grupo coliforme, o Escherichia coli, em 0,1 cm cúbico de amostra analisada, concluindose a "análise clínica de potabilidade: água em franca putrefação amoníaca"42.

Em 1957, numa matéria intitulada “As providências sugeridas há 20 meses não foram tomadas", a imprensa denunciava que:

[...] de agosto de 1954 a outubro de 1955, foram encontrados caramujos planorbídeos transmissores da esquistossomose em 26 municípios paulistas, em zonas rurais e urbanas [...] só na Capital, foram encontrados planorbídeos no Jardim da Aclimação, na Rua Dr. Cezar, na Quarta Parada, na estrada de Cangaíba, no Parque do Ibirapuera, no Joquey Club, na Estrada do Vergueiro e na Rua Santa Cruz ${ }^{43}$.

Nesse mesmo ano, numa conferência realizada no Instituto Butantã sobre "Alguns aspectos da esquistossomose no estado de São Paulo”, o médico José Manoel Ruiz explanou sobre a proliferação da doença no estado, principalmente no Vale do Paraíba e na Baixada Santista. Referindo-se à capital, foi enfático: "pelo exposto, concluímos que o problema da esquistossomose existe realmente em São Paulo, provavelmente em fase mais adiantada do que se supõe. Não só existe, mas está a exigir providências urgentes e realmente objetivas"44.

Foi em abril de 1958 que se reportaram pela primeira vez os primeiros casos autóctones na cidade:

\begin{abstract}
[...] estão internados no Hospital das Clínicas dois irmãos menores com diagnóstico de esquistossomose mansônica, na forma aguda da moléstia, que provavelmente adquiriram brincando em lagoas formadas às margens do Tietê, no Tatuapé. Há fortes suspeitas que se tenham verificado os dos primeiros casos autóctones dessa moléstia na capital de São Paulo, pois no local onde os meninos costumavam a brincar foram descobertos caramujos transmissores da doença 45 .
\end{abstract}

Indo além, identificaram-se os responsáveis pela situação: “nesse local, estão sendo feitas várias construções, e nelas trabalham vários nordestinos. Esses operários, procedentes de regiões onde a esquistossomose é endêmica, poderiam ter contaminado as águas" ${ }^{46}$.

${ }^{41}$ JORGE, J. Rios e saúde na cidade de São Paulo. História e Perspectivas (Uberlândia). 2012; 25(47): p. 122-123.

42 A Gazeta, 6 jul. 1945, p. 1.

43 O Estado de S. Paulo, 13 set. 1957, p. 5.

44 O Estado de S. Paulo, 9 nov. 1957, p. 10.

45 O Estado de S. Paulo, 2 mar. 1958, p. 1.

${ }^{46}$ O Estado de S. Paulo, 2 mar. 1958, p. 1. 
Continuando o tema no dia seguinte, ganharam atenção da reportagem as condições de moradia naquelas paragens e, mais uma vez, a presença de "nordestinos":

[...] na proximidade do local apontado, existem diversas lagoas à margem do rio Tietê. Ao redor delas, agrupam-se extensas favelas de casebres construídos com pedaços de madeira obtidos das fontes mais extravagantes. Montes de lixo depositados pela prefeitura no local acumulam-se, dando pasto para urubus. Nas margens das lagoas, cresce vegetação aquática exuberante, formando locais propícios para a criação de caramujos transmissores da moléstia. Nota-se, porém, que os moradores do local não conhecem os moluscos. Grande parte dos moradores da favela são nordestinos ${ }^{47}$.

Nos anos de 1960-70, os casos teriam aumentado e proliferado em 23 municípios paulistas, mesmo com algumas ações de erradicação da doença em curso, como no Vale do Paraíba em 1967. Contudo, a causa dos altos números identificados ainda era explicada unicamente pela chegada de nordestinos:

[...] vinte e cinco por cento dos migrantes que chegam a São Paulo, principalmente os que chegam dos estados do Nordeste, são portadores de esquistossomose e contribuem involuntariamente para a disseminação da doença na capital. $\mathrm{O}$ alto índice de contágio neutraliza em parte o trabalho da Campanha de Combate à Esquistossomose - Cacesq ${ }^{48}$.

Em 1975, a Cacesq propõe que se controle a entrada de migrantes em São Paulo e justifica a medida com os números alarmantes de 1973, quando teriam entrado no estado 21.055 portadores de esquistossomose. Reconhecia que "as condições de saneamento não acompanhavam convenientemente o desenvolvimento dos centros urbanos e que esses portadores se fixam onde são deficientes as condições sanitárias" ${ }^{49}$. Questão, é bom lembrar, que já havia sido tratada décadas em anteriores. Há um claro exemplo em 1952, quando o assistente de parasitologia médica da Faculdade de Medicina da Universidade de São Paulo Luis Rey deixou claro:

[...] quem percorria a periferia de São Paulo perceberia grande número de pequenas lagoas, sítios para a transmissão da esquistossomose, principalmente porque a população carente que viveria nas suas proximidades, utilizando dessas lagoas [...] além das favelas localizadas nas várzeas, áreas anteriormente vazias ou exclusiva das indústrias (Rey, 1956, p. 1).

Finalmente, é preciso relativizar as indicações que davam os nordestinos como a causa de todo o mal, pois "o fator migração, quando analisado independentemente de seus determinantes (a industrialização) e de suas consequências (o tipo de urbanização), perde poder explica-

${ }^{47}$ O Estado de S. Paulo, 3 abr. 1958, p. 3.

${ }^{48}$ O Estado de S. Paulo, 5 fev. 1972, p. 10.

49 O Estado de S. Paulo, 1 mar. 1975, p. 22. 
tivo no processo de disseminação da esquistossomose, ainda que nele tenha crucial importância" ${ }^{50}$. Indo além, numa avaliação histórica, há que retomar o modelo tecnológico de saúde pública estadual e municipal implicado no momento e em que medida ele conseguiria ou não enfrentar endemias desse porte. Ao que parece, a desarticulação em nível municipal das instâncias de saúde pública também explicaria a situação e seu recrudescimento, fato retirado da história oficial da saúde pública paulista. Assim, mais que a culpabilização de um grupo definido, é da complexa história da organização da cidade e das instituições voltadas ao cuidado da saúde pública que podemos apreender os meandros que teriam passado desapercebidos pelos levantamentos epidemiológicos, pelos estudos de caso e pelas notícias veiculadas pela imprensa.

\section{A epidemia que não houve, mas houve: meningite - 1945-1957}

Segundo os estudos sobre a meningite, antes de 1901, não há dados oficiais a respeito. Quanto a sua denominação, entre 1901-1937, ela foi chamada meningite cérebro-espinhal epidêmica. Retirado o termo epidêmica, acabou vigorando, em sua sexta e sétima revisão, a denominação meningite meningocócica ${ }^{51}$. Nesse primeiro período, os números registrados eram muito baixos, pois, sem a rotina dos exames de punção e liquor, provavelmente não se identificava claramente a doença. A partir de 1920, com a revisão do nome e os exames introduzidos no diagnóstico, os números começam a ascender e mesmo a oscilar entre contextos endêmicos e epidêmicos. No entanto, avançando até 1930-40, as autoridade sanitárias repisavam que não havia sombra dessa epidemia no ar, mas, em seu estudo sobre a meningite meningocócica em São Paulo, Barata e Moraes $^{52}$ afirmam que a epidemia se instalou a partir de 1945: “A taxa de incidência, que havia sido inferior a dois casos por 100.000 habitantes em 1944, passou abruptamente para quase nove casos para cada 100.000 habitantes em 1945. A epidemia atinge o pico máximo em 1947, e a incidência volta aos valores endêmicos em 1952".

Nesse sentido, desde 1945, podemos acompanhar na imprensa que vários pontos do estado de São Paulo vinham sendo atingidos por ondas epidêmicas de meningite, sempre, é claro, em pequenas notas, quase imperceptíveis para o leitor. Nesse ano, diziam as notícias que a epidemia havia chegado ao município de Paraíso, "tendo registrado vários casos fatais. A população

${ }^{50}$ Cf. SILVA, LJ, 1985, p.5-6.

${ }^{51}$ SCHMID, AW. Alguns dados epidemiológicos sobre a mortalidade de doenças transmissíveis respiratórias agudas no município de São Paulo (com uma crítica sucinta a respeito da morbidade e letalidade) (Tese de Doutorado em Saúde Pública), 1958, São Paulo: Faculdade de Higiene e Saúde Pública, Universidade de São Paulo, p. 316.

52 BARATA, RCB; MORAES, JC. A doença meningocócica na cidade de São Paulo. In: MOTA, A; MARINHO, MGSMC; BERTOLLI FILHO C. (organizadores). As enfermidades e suas metáforas: epidemias, vacinação e produção de conhecimento. São Paulo: FMUSP/UFABC/ CD\&G; 2015. p. 79. 
daquele município encontra-se intranquila, em vista de menos da sua quarta parte apenas estar vacinada, por falta de assistência oficial’’53. Em 1947, o mesmo jornal acusava:

\begin{abstract}
[...] a existência de um surto de meningite e gripe no interior de São Paulo. A primeira dessas doenças está assolando a população do Vale do Ribeira, enquanto a gripe atinge a cidade de Araras. O Departamento de Saúde do Estado já teve conhecimento do fato, sendo que a zona onde foi assinalada a meningite está compreendia entre Registro e Sete Barras ${ }^{54}$.
\end{abstract}

Em 1948, toda a região da mogiana estaria sendo atingida, sobretudo as cidades de Casa Branca, Tambaú, São João da Boa Vista, Santa Rosa e Fazenda Amália. Outro jornal deu destaque à região de Bauru e cidades vizinhas: "Surto de meningite em Bauru - Irrompeu na cidade de Pederneiras um surto de meningite cérebro-espinhal, tendo se verificado já oito casos. O avião, transportando socorros, partiu para Pederneira. Também da cidade de Bauru estão sendo enviados auxílios" ${ }^{5}$.

Já sobre a capital paulista, quase nada foi publicado. Em 1945, dizia uma tímida notícia: "um vespertino publicou uma reportagem ilustrada dizendo em manchete que uma epidemia de meningite começa a grassar em São Paulo. Diz que há vários bairros atingidos pela doença, citando Vila Prudente, Alpina e Lucile e os municípios de Santo André e São Caetano”56. De acordo com o levantamento de uma comissão nomeada pela diretoria geral do Departamento de Saúde, só em 1956 se admitiu que a meningite era das principais doenças que acometiam a população da cidade: "de acordo com a comparação de dados estatísticos feita pela comissão encarregada dos estudos, a difteria representou a mesma ameaça que a febre tifoide, a paratifoide, a poliomielite e a meningite meningocócica entre os anos de 1950-1955”57.

Contudo, durante esse período, houve um silêncio sobre sua dimensão epidêmica, reconhecida, somente, a posteriori. Conforme lembraram Barata e Moraes ${ }^{58}$, nenhum artigo científico discutiu a epidemia, e a postura das autoridades de saúde negava-a sistematicamente:

[...] pelo contrário, já na vigência dela em 1945, Mário Aguiar publicou um artigo questionando a designação habitual de meningite cérebro-espinhal epidêmica alegando que as epidemias de meningite nunca se expandem como as de gripe, cólera e outras doenças infecciosas, não passando de "epidemias de quarteirão" ou de focos esporádicos ${ }^{59}$.

Em 1957, quando a epidemia retrocedia, ainda se narravam episódios de meningite na cidade. Em O Estado de S. Paulo de 1957 (24 mar., p. 14) um leitor, morador do bairro de Perdizes,

\footnotetext{
${ }^{53}$ Correio Paulistano, 26 set. 1945, p. 3.

${ }^{54}$ Correio Paulistano, 31 jul. 1947, p. 12.

${ }^{55}$ Diário da Noite, 28 fev. 1948, p. 3 ,

${ }^{56}$ Correio Paulistano, 7 ago. 1945, p. 2.

57 O Estado de S. Paulo, 6 out. 1956, p. 16.

58 BARATA, RCB; MORAES, JC. 2015, passim.

${ }^{59}$ O Estado de S. Paulo, 6 out. 1956, p. 80.
} 
conta o adoecimento do filho: "quando a temida doença meningite sobreveio em 12 de janeiro de 1957 e o menino faleceu em dois dias, mesmo com todos os tratamentos". Em 1958, ou seja, um ano depois da refrega epidêmica, uma tese doutorado defendida na Faculdade de Higiene e Saúde Pública da USP estudou doenças transmissíveis e respiratórias e declarava:

De 1931 a 1944, existe uma pequena elevação nos primeiros anos e posteriormente uma queda, sendo sempre baixa a sua mortalidade. Em 1945, o coeficiente se eleva bruscamente, indicando uma onda epidêmica que perdurou por vários anos, chegando em 1957, novamente, numa baixa mortalidade ${ }^{60}$.

Observando as áreas mais atingidas da cidade, outra vez encontraremos claramente as camadas mais pobres atingidas, entre elas, os grupos migratórios que ainda acorriam em grande número à cidade:

[...] a epidemia produziu aumentos sensíveis na incidência em todas as áreas da cidade, porém, a distribuição espacial não se alterou demasiadamente. As maiores taxas foram observadas no distrito de Itaquera (Zona Leste) e no distrito de Perus (Zona Norte). Com taxas um pouco menores, mas ainda bastante altas, estavam os distritos de São Miguel (Zona Leste) e três distritos do centro: Sé, Bom Retiro e Santa Cecília. As áreas centrais mais afetadas eram aquelas nas quais concentravam-se habitações coletivas e moradias precárias ocupadas pelo proletariado e pelas camadas médias empobrecidas ${ }^{61}$.

Se a epidemia que durou de 1945 e 1957 não foi reconhecida, mas omitida pelas autoridades de saúde, fosse como tragédia ou como farsa, ela voltou a se alastrar pela capital na década de 1970, ganhando mais força, mesmo com o silêncio sobre os números assombrosos que, aos poucos, foram criando pânico entre a população. De acordo com Rita Barradas Barata (1985, p. 58/59):

[...] a epidemia de doença meningocócica pôs a descoberto a anarquia na organização dos serviços de saúde no município de São Paulo revelando a inoperância da rede hospitalar e a total falta de integração entre os serviços locais destinados ao primeiro atendimento e os hospitais [...]. A Secretaria de Estado da Saúde não tinha nenhum sistema efetivo de Vigilância Epidemiológica, limitando-se apenas a cadastrar os casos ocorridos no Hospital Emílio Ribas sem, entretanto, realizar qualquer tipo de análise epidemiológica.

Num artigo que expunha os órgãos de saúde pública por haverem ocultado o número de pacientes que superlotavam o Hospital Emílio Ribas, falou-se em 491 doentes só no segundo

${ }^{60}$ SCHMID, AW. 1958, p. 317.

${ }^{61}$ BARATA, RCB; MORAES, JC. 2015, p. 81. 
semestre de 1971. Numa entrevista tensa, o secretário da Saúde indicaria pela primeira vez os números que até então haviam sido omitidos:

[...] durante a entrevista, que foi acompanhada por representante da Organização Mundial de Saúde, enviado especialmente ao Brasil, o secretário e seus assessores afirmaram, mais uma vez, que a epidemia de meningite não é grave, deve neste momento entrar em declínio e não há motivo algum para que a população se alarme ${ }^{62}$.

No entanto, a epidemia tomava o país inteiro, com um aumento de 50\% dos casos, tendo no estado de São Paulo o número crescido de 573 casos em 1972 para 878 em 1973 63.

Em 1974, foi censurada uma página de O Estado de S. Paulo que repercutia o avanço da epidemia pelo país e por todo o estado de São Paulo. Despreparo, desinformação e inquietação social eram apontados em todos os estados brasileiros. Entre eles, num artigo chamado "A epidemia do silêncio", o jornalista Clovis Rossi descreveu como a doença vinha sendo tratada pelas autoridades médicas e de saúde:

[...] o surto de meningite que matou mais de 200 pessoas em São Paulo só nesse mês de julho não é lamentável apenas por suas consequências ou por revelar dramaticamente a precariedade do sistema de saúde de nosso estado, que se orgulha ser o mais rico da federação. Talvez ainda pior do que tudo isso seja o fato de que, com ele, atingiu seu ponto mais alto também a epidemia da desinformação e ocultamento dos fatos que as administrações públicas, em todos os níveis, resolveram desencadear, faz algum tempo. Se intensificou justamente quando se prometeu jogar o "jogo da verdade". Hoje, o que se pode ter é apenas um lado da verdade: o lado oficial, asséptico, geralmente ufanista o mais das vezes. Quem não aceita só esse lado que leia poesias ${ }^{64}$.

62 O Estado de S. Paulo, 30 set. 1972, p. 12,

${ }^{63}$ MORAES, JC; GUEDES, JS. Epidemiologia da meningite por Streptococcus pneumoniae em área metropolitana, Brasil, 1960-1977. Revista de Saúde Pública (São Paulo). 1990; 24: p. 354.

64 O Estado de S.Paulo, 26 jul. 1974, p. 1. 
Figura 2 - Matéria censurada pelas autoridades sanitárias paulistas durante a epidemia de meningite

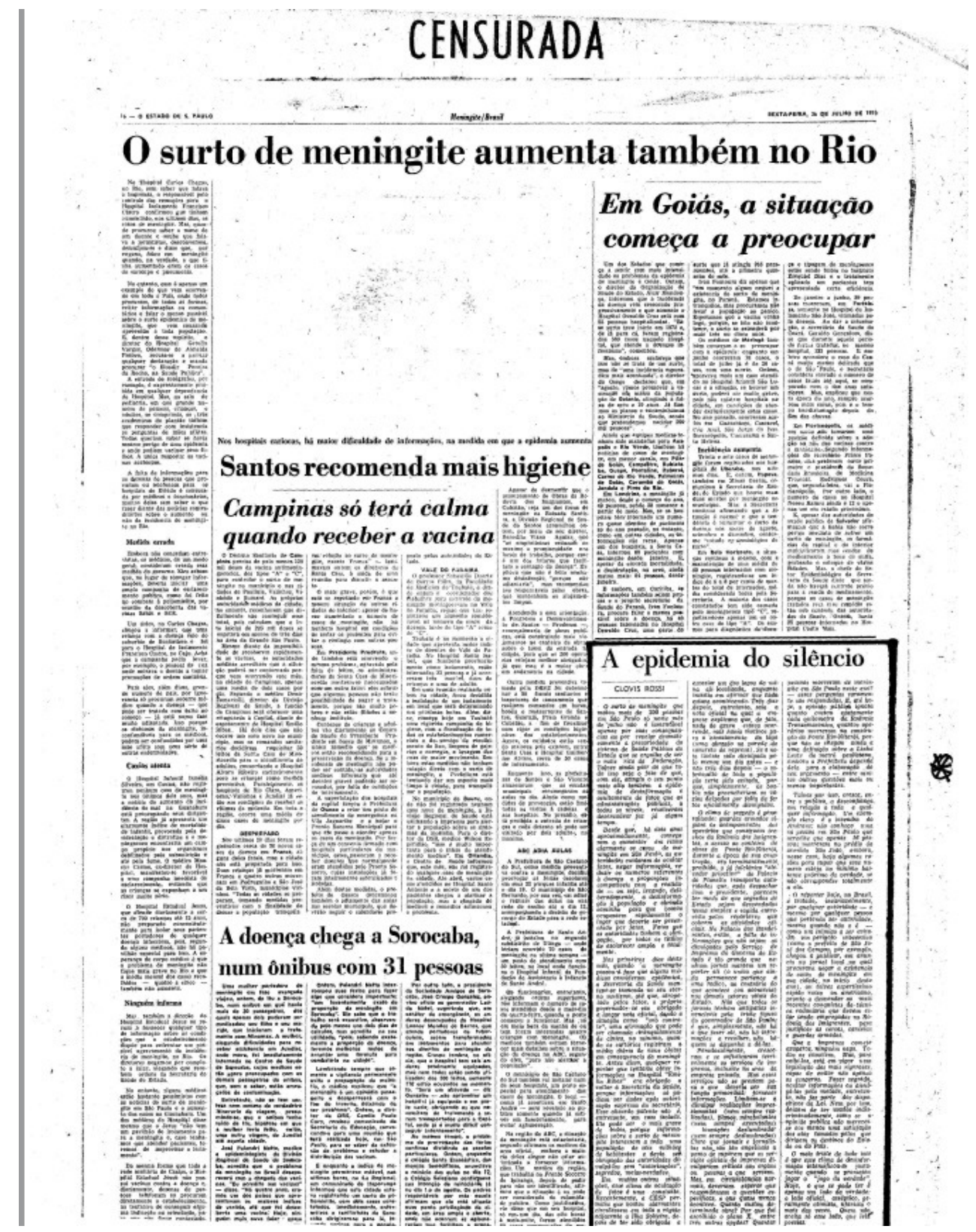

FONTE: O Estado de S.Paulo (26 jul. 1974).

A cidade industrial e a poluição do ar: doenças cardiorrespiratórias 1940-1970

Nos anos de 1930-40, tiveram início um processo decisivo na reestruturação da cidade de São Paulo e as apostas para sua (re)organização urbana:

[...] em 1930, o engenheiro Prestes Maia, então secretário de Obras do prefeito Fábio Prado, iniciou um Plano de Avenidas. Nessa gestão, foi construído o túnel Nove de Julho. O plano teve grande desenvolvimento 
nas gestões de Prestes Maia à frente da prefeitura nos períodos 19381945/1961-1965 e caracterizou-se como a maior intervenção urbanística já vista na cidade 65 .

Nesse período, então, os pressupostos urbanísticos aplicados pela administração municipal imprimem soluções técnicas universais e racionais, apartadas de sua vinculação social ou política, redundando em problemas desarticulados desse conjunto de ações administrativas (Feldman, 2013, p. 669). Teria sido nesse momento que passou a prevalecer a "lógica da industrialização", que não deve ser entendida como a mera criação de indústrias, mas como um processo social complexo, com a formação de um mercado nacional, os equipamentos gerados para sua integração, a expansão do consumo e o próprio processo de urbanização. São Paulo tinha aproximadamente dois milhões de habitantes e perto de 50 mil veículos, e, dada a concentração de empregos na área central, a maioria deles já se dirigia para lá todos os dias, acumulando-se cerca de 12 mil veículos entre $16 \mathrm{~h}$ e $17 \mathrm{~h}$ de um dia útil, ou $20 \%$ da frota da cidade ${ }^{66}$. Exemplarmente, na:

[...] cidade de São Paulo, em 1950, o risco de morrer por acidente de veículo a motor foi aproximadamente cinco vezes maior do que o devido à tuberculose (respectivamente 12,2 e 60,0/100.000 habitantes) e, em 1967, os acidentes mataram cerca de 1,4 vezes mais do que a tuberculose (respectivamente 24,2 e 17,3/100.000 habitantes). De 1950 para 1960, os níveis de mortalidade causada por esse tipo ide acidente permaneceram mais ou menos estacionários. A partir da década de 60 , porém, a mortalidade aumentou bastante, atingindo em 1970 valor que representa quase o dobro do verificado em $1960^{67}$.

Isso porque, diante do declínio do transporte ferroviário e da profusão de automóveis e rodovias, assistiremos às indústrias do município de São Paulo produzirem, muito acima da produção têxtil, materiais de transporte e elétricos. Assim, as atividades industriais passaram a emitir na atmosfera novos tipos de poluentes como ferro, cádmio, chumbo, cobre, berílio, cianetos, hidrocarbonetos, ácidos e solventes (Valentim, 2007, p. 32). Tudo isso revelou aspectos muito interessantes de certos males que vinham sendo identificados e vinculados à poluição, como as doenças cardiovasculares (DCV), que acusaram "tendência crescente até 1952, quando passaram a apresentar uma flutuação, ora aumentando, ora diminuindo, porém, sempre mostrando níveis superiores aos observados entre 1940-1949”68.

${ }^{65}$ LEMOS, JF. Poluição veicular: avaliação dos impactos e benefícios ambientais com renovação da frota veicular leve na cidade de São Paulo [dissertação]. São Paulo; Escola Politécnica, Universidade de São Paulo, 2010, p.22.

${ }^{66}$ VASCONCELOS, EA. Circular é preciso, viver não é preciso: a história do trânsito na cidade de São Paulo. São Paulo: Annablume/Fapesp, 1999, p. 71.

${ }^{67}$ LAURENTI, R; FONSECA, LAM. A mortalidade por doenças cardiovasculares no município de São Paulo em um período de 30 anos (1940-1969). Arquivos Brasileiros de Cardiologia (Rio de Janeiro). 1976; 29(2): p. 330.

${ }^{68}$ Ibidem, p. 48 
Cabe ainda observar que, paralelamente aos limites da cidade de São Paulo, outros adensamentos populacionais concorreriam para recrudescer tal quadro, quando áreas metropolitanas receberam grande contingente industrial, caso exemplar do ABC paulista. Isso porque, “em 1950, essas regiões tinham apenas $27 \%$ de redes de água e esgoto, continuando os outros $73 \%$ a depender do serviço de fossas. Ao adensamento populacional, que em 1970 chegou à casa de um milhão de habitantes, somavam-se essas condições de vida, com as fábricas expelindo diariamente poluentes no ar (Venâncio, 2012, p. 27).

Nos anos 1950-60, a relação entre a poluição do ar e as doenças dela provenientes já estava nos discursos políticos e nos jornais. Em 1957, ao se anunciarem as atividades da Assembleia Legislativa de São Paulo, já havia um pedido de regulamentação de lei, do deputado Scalamandré Sobrinho, do PTN, para o controle da poluição atmosférica na cidade:

[...] a situação na Capital é alarmante. Por volta das 18 horas, no Largo da Sé, o ar atmosférico é insuportável. Uma verdadeira fábrica de moléstia, uma fábrica de doenças. E o câncer anda rondando os pulmões dos infelizes paulistanos que por lá transitam. Igual fato sucede no Brás, e no Ipiranga, como em São Caetano do Sul, em consequência de existirem naqueles distritos e no vizinho município grande número de fábricas. É necessário que o governo tome imediatamente uma providência nesse sentido. No que diz respeito à praça da Sé, é preciso que os ônibus da CMTC sejam vistoriados de maneira a não despejarem fumaça naquela parte central da cidade ${ }^{69}$

Também o Jornal do Brasil se posiciona, na matéria "Poluição do ar mata na Grande São Paulo", afirmando que a taxa de mortalidade por bronquite teria aumentado $140 \%$ :

[...] segundo o engenheiro da OMS, em cada grupo de 100 mil habitantes, entre 1952 e 1960, a taxa de mortalidade por bronquite aumentou de 4,72 para 11,24. Essa enfermidade geralmente está ligada à contaminação do ar, e esse aumento verificado não pode ser atribuído a uma relação cau$\mathrm{sal}^{70}$.

Em levantamento realizado em 1962 apontando as principais causas dos óbitos ocorridos na cidade, essas questões se reforçam:

[...] $1^{\circ}$ Doenças do coração, $2^{\circ}$ Neoplasmas malignos, $3^{\circ}$ Lesões vasculares do S.N.C., $4^{\circ}$ Pneumonia e broncopneumonia, $5^{\circ}$ Gastrite e duodenite, $6^{\circ}$ Tuberculose, $7^{\circ}$ Todos os acidentes, $8^{\circ}$ Diabetes, $9^{\circ}$ Vícios de conformação congênita, $10^{\circ}$ Acidentes de veículos automotores ${ }^{71}$.

Em 1964, o ABC paulista apresentava-se como área perigosa em função dos poluentes despejados diariamente na atmosfera. Seriam:

\footnotetext{
${ }^{69}$ O Estado de S. Paulo, 26 jun. 1957, p. 6.

70 Jornal do Brasil, 21 jul. 1967, p. 10.

${ }^{71}$ MASCARENHAS, RS. Problemas de saúde pública no município de São Paulo. Arquivos da Faculdade de Higiene e Saúde Pública da Universidade de São Paulo (São Paulo). 1965; 19(12-): p.13.
} 
[...] gazes tóxicos, poeiras industriais e fumaças nocivas lançadas às toneladas todos os dias na atmosfera da região. Tão agravada se encontra a situação que, segundo levantamento feito por autoridades sanitárias de São Paulo, a incidência de bronquite por 100.000 habitantes elevou-se de 1 a 12 , nestes seis últimos anos. Asseveram os relatórios que as doenças graves nas vias respiratórias e mesmo o câncer pulmonar teriam relação com a poluição atmosférica regional ${ }^{72}$.

Em 1967, as doenças cardíacas aparecem como centrais e diretamente ligadas à poluição ar:

[...] a poluição atmosférica provoca uma série de acidentes no homem, e parte da população mais atingida é o grupo que apresenta doenças cardiorrespiratórias - esta é a principal conclusão a que chegou o Serviço de Controle da Poluição Atmosférica do Instituto de Engenharia Sanitária da Sursan ${ }^{73}$.

Também em 1967 cancerologistas admitiam que, a partir de partículas expelidas pelas fábricas, a poluição do ar provocaria câncer pulmonar. Segundo relatório: “a fumaça expelida por qualquer instrumento, em grande quantidade, é um elemento cancerígeno, sendo a contaminação atmosférica responsável pela alta incidência de câncer pulmonar que se vem verificando ultimamente em centros populosos, em grande contraste com as regiões rurais" ${ }^{\prime \prime 4}$. Os resultados dessa situação logo se fizeram se sentir oficialmente. Num levantamento das principais morbidades em São Paulo entre 1970-74, de acordo com dados dos Centros de Saúde da Capital e Grande São Paulo, agrupados em 17 danos baseados nas principais categorias da Classificação Internacional de Doenças, Lesões e Causas de Óbito: “o dano mais atuante dentro da demanda ambulatória de nossas unidades sanitárias é o representado pelas doenças agudas do aparelho respiratório, a indicar estreita correlação com a poluição atmosférica da área” (idem). Revela-se, pois, que no período já havia uma consciência médica e sanitárias dos efeitos dos poluentes na saúde da população e da necessidade de medidas urgentes para controlá-los.

Em 8 de dezembro de 1957, no artigo "Já há lei contra a poluição do ar em São Paulo: o problema é cumpri-la", o jornal Folha da Tarde traz informações sobre a Lei n. 3.798, que estabelece que os resíduos gasosos de origem industrial ou de qualquer outra fonte de emissão só poderiam ser lançados na atmosfera após processo de despoluição e "prevê, ainda, a lei que pessoas físicas e jurídicas infratoras serão punidas com multa de dez mil cruzeiros, elevada ao dobro a reincidência, interditando a autoridades competente as instalações causadoras da poluição atmosférica [...]" ${ }^{75}$. No entanto, a própria lei já era considerada mais uma medida sem efeito prático, devido à falta de infraestrutura para as ações de fiscalização cabíveis:

[...] evidentemente, a Secretaria de Saúde não está aparelhada para desenvolver as atividades que lhe são cometidas pelo texto legal ora sancionado. O que há naquela Secretaria, em matéria de pesquisa de poluição do ar, é

\footnotetext{
72 O Estado de S. Paulo, 10 maio 1964, p. 11.

73 Correio da Manhã, 3 jan. 1967, p. 1.

74 Jornal do Brasil, 23 maio 1967, p.7.

${ }^{75}$ Folha da Tarde, 8 dez. 1957, [s.p.].
} 
algo muito rudimentar. Em um laboratório mal aparelhado que pertenceu à fiscalização e Higiene ao Trabalho, um médico idealista, o Sr. Heitor Pinto Tameirão, e um assistente fizeram as primeiras observações da poluição atmosférica em São $\mathrm{Paulo}^{76}$.

Quase um ano depois de sancionada a lei, o diretor do Serviço de Epidemiologia e Profilaxia Gerais da Secretaria de Saúde, Favorino Prado, se pronunciou sobre o tema, defendendo que as primeiras ações estariam em curso, por meio da formação técnica de fiscais para executá-la. Segundo estimativas do período, haveria 325 mil estabelecimentos na capital paulista e na Grande São Paulo a emitir resíduos gasosos na atmosfera, além dos poluentes dos tubos de escapamento dos veículos, estes ainda não incorporados à lei sancionada. Em suas palavras:

[...] estamos começando a pôr em execução a lei contra a poluição do ar. Conseguimos, para isso, algumas viaturas e escalamos certos fiscais para a tarefa. Evidentemente, a campanha contra a contaminação da atmosfera precisa ser encarada com seriedade e levada a cabo com energia, pois São Paulo, conforme se sabe, é uma das cidades de ar mais poluído do país [...] as diligências que ora começam a ser feitas, por equipes de Epidemiologia, têm por finalidade classificar as fumaças lançadas ao ar pelas fábricas da cidade. Para isso, é usada a tabela de Ringhelmann, dispositivo simples que permite aferir a densidade da fumaça, pela sua cor, de certa distância. A cor do fumo, no caso, é comparada com o sombreado de certos quadriláteros de cartão, preparados de acordo com determinada técnica ${ }^{77}$.

No curso realizado nos dias 1 e 2 de dezembro de 1958 na Faculdade de Saúde Pública da Universidade de São Paulo, os engenheiros Silas Fonseca Redondo e Julio Rabin discutiram respectivamente "Agentes e fatores da poluição atmosférica" e "O controle de combustão na prevenção da poluição do ar". No segundo dia, as aulas versaram sobre "Efeitos da poluição do ar sobre a saúde", "O problema das fumaças dos veículos a motor", "A situação da poluição atmosférica em São Paulo" e "Legislação sobre poluição atmosférica"78.

Em 1959, uma nova reunião entre representantes da Secretaria da Saúde e da indústria passou a atacar as primeiras normas que constariam da segunda parte da lei, que ainda não havia sido sancionada, ou seja, referentes à fiscalização de fontes poluidoras como veículos, fornalhas etc. A presença da Associação Brasileira de Combustão também era tida como fundamental para os encaminhamentos. Se não culminaram numa ação política, as dificuldades para imputar responsabilidades ou identificar a causa de certas doenças exclusivamente à inalação de poluição atmosférica ganharam combate pela indicação do Congresso Mundial de Poluição Atmosférica, realizado em Buenos Aires no ano de 1965.

Por ele, formou-se, em 1966, a Associação Brasileira de Prevenção à Poluição do Ar (ABPPOLAR). Seguindo associações desse gênero criadas na Alemanha, na Inglaterra, no Japão

${ }^{76}$ Folha da Tarde, 8 dez. 1957, [s.p.].

77 Folha da Tarde, 19 nov. 1958, [s.p.].

${ }^{78}$ Folha da Tarde, 27 nov. 1958, [s.p.]. 
e na Argentina, a ABPPOLAR era constituída por empresários e autoridades ligadas a questões da poluição do ar, assumindo que:

\begin{abstract}
[...] a elevada densidade demográfica das populações aliada ao desenvolvimento industrial e ao crescimento vertiginoso do número de veículos motorizados em circulação trazem como consequência problemas de poluição do ar, com reflexos na saúde da coletividade, nos animais, vegetais e prejuízos econômicos ${ }^{79}$.
\end{abstract}

Nesse mesmo ano de 1966, entre os dias 5 e 10 de dezembro, organizou-se o Seminário sobre a Poluição do Ar, promovido pela Organização Mundial de Saúde, pela Organização Panamericana de Saúde e pela Faculdade de Higiene da USP, sendo coordenador geral o professor Walter Engracia de Oliveira". Devido ao fato de a poluição não ter limites municipais para se expandir, caso especial da Grande São Paulo, formaram-se nesse período a Comissão Intermunicipal de Controle de Poluição das águas e do $\operatorname{Ar}$ (CICPAA) e o Grupo de Estudos da Grande São Paulo (Gegram), órgãos que passaram a atentar para as questões relativas à poluição do ar, principalmente nesse momento, quando se identificaram índices de poluição superiores a $90 \%$, em comparação com as cidades de Londres e Los Angeles.

\title{
Considerações Finais
}

Os estudos historiográficos sobre São Paulo à luz do paulistanismo, ou seja, essa representação que faz pensar o estado como uma locomotiva capaz de levar a reboque o resto da nação, será sempre uma ameaça aos analistas, que, desavisados dessa simbologia, acabam por aprofundar uma versão regional eivada de apriorismos em torno da modernidade salvadora. Seria uma narrativa que busca também numa certa memória da saúde pública paulista uma história linear, progressiva e inacabada, cabendo a seus representantes do tempo vivido completá-la ad infinitum. Como expressão maior dessa história em construção, as instituições científicas e de saúde pública receberiam os louros por suas pretensas "naturais" conquistas, refletidas na qualidade dos serviços prestados, nos estabelecimentos sanitários e em hospitais de todo o estado e da capital.

Ledo engano. Ao priorizar a cidade de São Paulo e a vida de sua população pobre e vulnerável, queremos dizer que os esforços empreendidos também têm caráter limitante para a saúde. Que a redemocratização chega nos anos 1980 esfacelada em meio a grandes desilusões e impossibilidades de avanço, em maio as idas e vindas da construção do federalismo brasileiro ${ }^{80}$.

79 O Estado de S. Paulo, 26 maio 1966, [s.p.].

${ }^{80}$ HOCHMAN G. Saúde pública e federalismo: desafios da Reforma Sanitária na Primeira República. In: HOCHMAN, G; FARIA, CAP. Federalismo e políticas públicas no Brasil. Rio de Janeiro: Fiocruz; 2013. p. 303-27. 
Esse é o motor da História, para retomarmos Walter Benjamin, ou seja, a contrapelo da análise é que se veem as possibilidades de mudança; identificando avanços, sim, mas sobretudo reconhecendo os recuos, podendo dar novo sentido ao presente. Quando encontramos, atualmente, nos cortiços e periferias da capital paulista, uma população sem direitos mínimos à saúde, como saneamento básico e água tratada, por exemplo, surge o mal-estar que exige historicidade, a compreensão de que a defesa do Estado Mínimo pode ser mais um Cavalo de Troia a esconder as idiossincrasias de nossas elites e o embrutecimento da própria nação brasileira. 